\title{
CONTEMPORARY POLITICAL THEORY ANNUAL PRIZE OF $£ 500$ FOR AN ARTICLE PUBLISHED IN VOLUME 7, 2008
}

We are delighted to announce that the Contemporary Political Theory Annual Prize for 2008 has been awarded to Elizabeth Frazer, New College, Oxford, UK and Kimberly Hutchings, London School of Economics, UK, for their article, 'On Politics and Violence: Arendt Contra Fanon', published in volume 7, number 1.

The panel of judges, Russell Keat, John Maynor and Gary Browning were unanimous in awarding the prize to Elizabeth Frazer and Kimberly Hutchings. Their article was seen to be a critical and lucid analysis of the relationship between politics and violence, which is of general interest to a political theory audience. It presents an intelligent reading of what can be learnt from a critical comparative review of how Fanon and Arendt take politics and violence. The significance of the subject manner and the article's skilful focus upon theorists from differing traditions render this article a worthy winner of the prize. 